\title{
State Power, Religion, and Women's Rights: A Comparative Analysis of Family Law
}

\author{
Mala Htun \\ New School for Social Research \\ S. Laurel Weldon \\ Purdue University
}

Follow this and additional works at: https://www.repository.law.indiana.edu/ijgls

Part of the Family Law Commons, International Trade Law Commons, Law and Gender Commons, and the Religion Law Commons

\section{Recommended Citation}

Htun, Mala and Weldon, S. Laurel (2011) "State Power, Religion, and Women's Rights: A Comparative Analysis of Family Law," Indiana Journal of Global Legal Studies: Vol. 18 : Iss. 1 , Article 7.

Available at: https://www.repository.law.indiana.edu/ijgls/vol18/iss1/7

This Symposium is brought to you for free and open access by the Law School Journals at Digital Repository @ Maurer Law. It has been accepted for inclusion in Indiana Journal of Global Legal Studies by an authorized editor of Digital Repository @ Maurer Law. For more information, please contact rvaughan@indiana.edu.

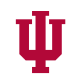

JEROME HALL LAW LIBRARY INDIANA UNIVERSITY Maurer School of Law
Bloomington 


\title{
State Power, Religion, and Women's Rights: A Comparative Analysis of Family Law
}

\author{
MALA HTUN ${ }^{*}$ AND S. LAUREL WELDON ${ }^{\star *}$
}

\begin{abstract}
Examining cross-national variation in family law, we find that many countries have reformed to promote sex equality. Yet a significant group retains older laws that discriminate against women. These variations reflect the diverse institutional legacies of these societies, conforming closely-but not entirely-to inherited legal traditions: civil law, common law, and postsocialist countries are the most egalitarian, while countries applying religious law are the least. Yet change is possible, even in unlikely contexts. Political conjunctures that disarm religious, nationalist, and fundamentalist opponents can open windows of opportunity for liberalizing reform.
\end{abstract}

\section{INTRODUCTION}

Family law-also called personal status law-shapes virtually every aspect of a woman's life. It determines her status at birth; her capacity to own, inherit, and manage property; her freedom to work, marry, divorce, and remarry; and her relationship with her children. Unfortunately, family laws in most of the world tend to maximize men's power over women and limit women's ability to make decisions and take independent action.

In much of Europe and North America, family laws were historically patriarchal. Women's rights began to expand only at the end of the nineteenth and the beginning of the twentieth century as AngloAmerican countries adopted married women's property acts and as Nordic countries introduced mutual consent and eliminated fault

* Mala Htun is Associate Professor of Politics at the New School for Social Research in New York City and Visiting Associate Professor of Political Science at the University of New Mexico.

** S. Laurel Weldon is Professor of Political Science at Purdue University.

Indiana Journal of Global Legal Studies Vol. 18 \#1 (Winter 2011)

(c) Indiana University Maurer School of Law 
grounds for divorce. ${ }^{1}$ Yet family law was fully liberalized only in the last third of the twentieth century, under pressure from women's growing economic independence and the rise of fresh ideas about their social status and rights. ${ }^{2}$ Communist countries in the West and East also liberalized family law at various points during the twentieth century in part to free women to participate in the workforce and in part to curtail the sphere of religious influence. ${ }^{3}$

In other places, such as the Middle East and parts of South Asia, trends toward family law liberalization are more uneven. In spite of the growth of the feminist movement, worldwide trends toward democracy, and the diffusion of international norms on human rights, family, and personal status laws have remained discriminatory in many countries. These restrictions are consequential for more than women's autonomy and dignity, as they have broader implications. Societies that subordinate women are more likely to be authoritarian, and their populations poor, uneducated, unhealthy, and demographically imbalanced, with high rates of population growth. 4

This article offers a picture of the global variation in family law. We show that cross-national differences are significant: a large group of countries have eliminated sex discrimination while a handful, including Saudi Arabia, Egypt, and Iran, continue to disadvantage women in numerous ways. In this latter group, religious personal status laws have held sway. Indeed, we find that the status of women in family law is roughly correlated with a country's traditional legal system. Civil law, common law, socialist and postsocialist, and Nordic countries have done

1. The Swedish divorce law of 1915 went a step further by proposing that wives be liberated from dependence on their husbands. See generally MARY ANN GLENDON, THE TRANSFORMATION OF FAMILY LAW 124, 182-85 (1989).

2. See id. at 292 ("True, the edifice of traditional family law remained standing until the $1960 \mathrm{~s}$. . . The past twenty years have witnessed the movement from undercurrent to mainstream in family law of individualistic, egalitarian, and secularizing trends that have been gaining power in Western legal systems since the late eighteenth century."); see generally MARY ANN GLENDON, ABORTION AND DIVORCE IN WESTERN LAW (1987) (exploring the fundamental change in divorce and abortion regulation in the United States and Europe between 1967 and 1985); MAX RhEINSTEIN, MARRIAGE STABILITY, DivorCE, AND THE LAW (1972) (discussing the movement in the United States and England to liberalize divorce laws throughout the twentieth century); Harry Krause, Comparative Family Law, in OXFORD HANDBOOK ON COMPARATIVE LAW 1099 (2006).

3. See Kay Ann Johnson, Women, the Family and Peasant Revolution in China $97-98$ (1983); Maxine Molyneux, Family Reform in Socialist States: The Hidden Agenda, 21 FEMINIST REV. 47, 49, 55, 59 (1985); see generally MARY ANN GLENDON ET AL., COMPARATIVE LEGAL TRADITIONS IN A NUTSHELL (2008).

4. See M. Steven Fish, Islam and Authoritarianism, 55 WORLD POL. 4, 24-29 (2002); see generally JEAN DRÈzE \& AMARTYA SEN, INDIA: DEVELOPMENT AND PARTICIPATION 229. 271 (2d. ed. 2002); AMARTYA SEN, DEVELOPMENT AS FREEDoM (1999); MARTHA C. Nussbaum, WOMEN AND HuMAN DEVELOPMENT: THE CAPABILITIES APPROACH (2000). 
the most to eliminate discrimination while countries with religiously inspired family law-particularly those based on Shariah law-have done the least. Postcolonial states with multiple legal systems are somewhere in the middle.

The strong influence of religious authority and institutional legacies on family law offers a contrast with other areas of women's rights such as violence against women and political representation. ${ }^{5}$ In these latter areas, countries from diverse cultures and regions made common progress toward reform. Developing countries including India, Bangladesh, and Indonesia have introduced measures to combat violence against women and promote their political leadership, but have maintained restrictive family laws. Yet religious and legal traditions do not wholly determine outcomes. Some countries-including Morocco, Turkey, and Botswana-changed legislation virtually overnight, catapulting them from the group of most discriminatory countries to among the least.

What accounts for these divergent approaches to family law? Why are laws of personal status so seemingly resistant to change in some places? How can we explain both this resistance and the overall trend toward sex equality? ${ }^{6}$

By presenting some preliminary evidence of worldwide trends in family law, we hope to begin to answer these questions. Until now, there has been little worldwide comparative analysis of family law. ${ }^{7}$ Many existing studies focus on single regions (particularly the West), ${ }^{8}$ or

5. See generally MONA LENA KROOK, QUOTAS FOR WOMEN IN POLITICS: GENDER AND CANDIDATE SELECTION REFORM WORLDWIDE (2009) (discussing available remedies to provide political representation for women and other underrepresented groups); $S$. Laurel Weldon, Protest, Policy, and the Problem of Violence Against Women: A Cross-National COMPARISON (2002); Mala Htun, Is Gender like Ethnicity? The Political Representation of Identity Groups, 2 PERSP. ON POL. 439 (2004).

6. This paper focuses on sex equality. For a discussion of the term "sex equality," see Mala Htun and S. Laurel Weldon, When Do Governments Promote Women's Rights? A Framework for the Comparative Analysis of Sex Equality Policy, 8 PERSP. ON PoL. 207, 208 (2010) (explaining that "sex equality policy is a narrower category than gender policy for it concentrates more on equality between men and women and less on normative heterosexuality."). The achievement of sex equality is related-but not equivalent-to the elimination of sex discrimination in the law.

7. For exceptions, see the articles in 4 INTERNATIONAL ENCYCLOPEDIA OF Comparative Law: Persons and Family (Aleck Chloros, Max Rheinstein, \& Mary Ann Glendon eds., 2007) [hereinafter ENCYCLOPEDIA] and the articles on "The Politics of Religion and Gender Equality" in 31 THIRD WORLD QUARTERLY, no. 6, 2010. See also JOHN L. EsPosito WITH NATANA J. DeLONG-BAS, WoMEN IN MUSLIM FAMILY LAW (2d ed. 2001) (drawing examples from the Middle East, South Asia, and Southeast Asia); WOMEN LIVING UNDER MUSLIM LAWS, KNOWING OUR RIGHTS: WOMEN, FAMILY, LAWS, AND CUSTOMS IN THE MUSLIM WORLD (3d ed. 2006).

8. See generally MouniRa M. ChaRRAD, States AND Women's Rights: THE MaKing of Postcolonial TUNisia, Algeria, AND MOROcCo (2001); Glendon, supra note 1, at 3 
detailed analyses of particular cases, ${ }^{9}$ or are more theoretical than explanatory. 10 From these works we know that family law varies dramatically, but we lack a systematic, side-to-side comparison enabling us to test hypotheses about the causes of difference and the reasons for change. This is the purpose of the present study.

\section{BACKGROUND}

Historically, churches, clans, and cultural groups administered matters related to birth and death, partnering and procreation, property and inheritance, and the other myriad affairs that we today call family law. The modern state's claim over this domain is relatively recent, uneven, and, in much of the world, still incomplete. ${ }^{11}$ Prospects for family law reform thus touch upon the delicate balance between state power and the status of subnational groups. Trends in family law are intimately connected to church-state relations, the consolidation of state power, and the assertion of cultural and national identity.

Though most states have codified family law, much of it conforms to religious principles, at least partially, if not entirely. Early marriage

(focusing on England, France, Sweden, the United States, and West Germany); GLENDON, supra note 2; MALA HTUN, SEX AND THE STATE: ABORTION, DIVORCE, AND THE FAMILY UNDER LATIN AMERICAN DiCTATORSHIPS AND DEMOCRACIES (2003); AMY G. MAZUR, Theorizing Feminist Policy (2002); Muna NdUlo \& Margaret Grieco, Power, GENDER AND SOCIAL CHANGE IN AFRICA (2009); Valentine M. Moghadam, Gender and Social Policy: Family Law and Women's Economic Citizenship in the Middle East, in SOClal POLICY IN THE Middle EAST: ECONOMIC, POLITICAL, AND GENDER DYNAMICS (Massoud Karshenas \& Valentine M. Moghadam eds., 2006).

9. The literature, particularly in legal studies, is too vast to cite. For some examples, see Harald Fuess, Divorce in Japan: Family, Gender, and the STATE, 1600-2000 (2004); Rina Verma Williams, Postcolonial Politics and Personal laws: Colonial LEGAL LEGACIES AND THE INDIAN STATE (2006); Andreas Rahmatian, Termination of Marriage in Nigerian Family Laws: The Need for Reform and the Relevance of the Tanzanian Experience, 10 INT'L J.L. POL. \& FAM. 281 (1996) (discussing Tanzanian Law of Marriage Act of 1971); Jeanne Maddox Toungara, Inventing the African Family: Gender and Family Law Reform in Cote D'lvoire, 28 J. Soc. HIST. 37 (1994) (discussing family law in the Ivory Coast and the Association des Femmes Ivoiriennes); Egypt: Ensure Women's Equal Right to Divorce: Despite Reforms, Women Suffer Discrimination under Legal System, HuMAN RIGHTS WATCH (Nov. 28, 2004) [hereinafter HuMAN RIGHTS WaTch], http://www.hrw.org/en/news/2004/11/28/egypt-ensure-womens-equal-right-divorce (declaring that Egypt's family laws that regulate divorce discriminate against women).

10. See, e.g., AYElET SHaChaR, MUlTiCUltural JURISDictions: CUlTURAL DifFERENCES AND WOMEN'S RIGHTS (2001); SARAH SONG, JUSTICE, GENDER, AND THE POLITICS OF MULTICULTURALISM (2007).

11. This is not to say that political leaders never weighed in on family matters. Hammurabi's Code (1780 B.C.), widely believed to be the first codification of law, contains numerous provisions on marriage, divorce, adultery, and inheritance. 
laws in Western Europe, for example, were largely copied from canon law and other Christian teachings. ${ }^{12}$ Religious influences persisted in Western law well into the twentieth century. For example, divorce remained illegal in Italy until 1970; in Spain, until 1981; and in Argentina, until 1987. In Brazil and in Ireland, the principle of marital indissolubility remained in the constitution until 1977 and 1995, respectively. ${ }^{13}$

In parts of the Middle East, Northern Africa, and Southeast Asia, state-administered family law has continued to conform closely to religious teachings. Laws of personal status codified in Morocco in 1958, Iraq in 1959, Pakistan in 1961, Jordan in 1976, and Algeria in 1984, for example, are based largely on classical Shariah, albeit with variation and with some modifications designed to protect women. ${ }^{14}$

In other parts of the world, cultural traditions and inherited practices-also called customary law, African jurisprudence, and usos $y$ costumbres-reign alongside state-sanctioned family law or religious law. In these countries with multiple legal systems-most of which are former British colonies-different family laws apply, at least in theory, to different categories of people. In India, for example, Hindu law applies to Hindus and Muslim law to Muslims. ${ }^{15}$ Kenya recognizes four different legal regimes: civil statutes, Hindu law, Muslim law, and customary law. ${ }^{16}$ The demarcation of these spheres of legal authority can also be geographical, such as in Nigeria, where Shariah is commonly applied in the North, and customary and statutory law in the South. ${ }^{17}$

Notwithstanding these enduring religious influences-which persist even in countries found to be relatively secular by the World Values Survey ${ }^{18}$-many countries eliminated sex discrimination in family law over the course of the twentieth century. Nordic countries began to change first, followed by continental European and Anglo-American

12. GLENDON, supra note 1 , at 31 .

13. HTUN, supra note 8, at 95, 178-79; see generally RODERICK PHILLIPS, UNTYING THE KNOT: A SHORT HISTORY OF DIVORCE (1991).

14. For a discussion of these laws and their impact, see ESPOSITO WITH DELONG-BAS, supra note 7; WOMEN LIVING UNDER MUSLIM LAWS, supra note 7.

15. FlaVIA AGNES, LAW AND GENDER INEQUALITY: THE POLITICS OF WOMEN's RIGHTS IN INDLA 42-43, reprinted in WOMEN AND LAW IN INDLA (2004).

16. Nancy Baraza, Kenya Law Reform Comm'n, Family Law Reforms in Kenya: An Overview, Presentation at the Heinrich Böll Foundation's Gender Forum 4 (Apr. 30, 2009), available at www.boell.or.ke/downloads/Nancy_Baraza_-_Family_Law_Reforms_in_Kenya.pdf.

17. Rahmatian, supra note 9 , at 281-82.

18. See Ronald Inglehart \& Wayne E. Baker, Modernization, Cultural Change, and the Persistence of Traditional Values, 65 AM. Soc. REV. 19, 46-48 (2000); see generally Ronald Inglehart \& Pippa Norris, The True Clash of Civilizations, 135 FOREIGN POL'Y 62 (2003). 
counterparts. Latin American countries, strongly influenced by the European trends, changed later.

In these regions, provisions granting women equal rights over property and parenting replaced laws upholding male power and prerogatives. Rules obliging wives to obey their husbands were eliminated, as were requirements that wives seek their husbands' permission to work, open a bank account, and appear in court. Divorce was liberalized and requirements of proving cause-such as adultery, abuse, or abandonment-were removed in favor of no-fault divorce. Laws eliminated punishments for nonmarital sex and began to recognize the effects of nonmarital unions, ${ }^{19}$ including same-sex unions. ${ }^{20}$ Our study reflects some, but not all, of these sweeping changes.

Fierce political struggles preceded these legal changes. Feminist movements, liberal lawyers, and state modernizers-organized against a backdrop of profound social changes brought about by women's entrance into the labor force, a decline in fertility, and growing education levels-pushed countries toward reform. Often, they encountered resistance from opponents, claiming that granting women equal rights would destroy family unity, and from religious authorities-including bishops of the Roman Catholic Church-who maintained that liberalizing divorce would undermine the institution of marriage. ${ }^{21}$ In Latin America, changes to family law were further complicated by political transitions and the institutional fragility of new democracies. ${ }^{22}$

Other conflicts have played out on the terrain of family law. In many formerly colonized countries, for example, decolonization has caused national elites to reimagine and reinvent indigenous traditions, contrasting them to Western mores. Cultural authorities and entrepreneurial politicians have reasserted customary and religious family laws as a nation-building project, often in ways that erase gains in women's rights. These linkages between traditional gender roles and national identity make it possible to frame efforts to advance women's rights as unpatriotic. Family law reforms in Kenya and Uganda, for example, have been defeated in Parliament by opponents claiming that

19. See GLENDON, supra note 1 , at 252-284.

20. Mary Ann Glendon, Introduction: Family Law in a Time of Turbulence, in ENCYCLOPEDIA, supra note 7, at 9-11.

21. For a discussion of the resistance from the Church, see HTUN, supra note 8, at 78 . 112.

22. See generally id. (discussing how political and social transformations shaped state policy on abortion, divorce, and equality in the family in Argentina, Brazil, and Chile). 
they assaulted local customs. ${ }^{23}$ The subtle fact that traditions are always contested and multiple is lost in movements equating family law reform with capitulation to Western imperialism.

\section{DATASET AND METHODS}

As part of a larger, NSF-funded project on sex equality in law and policy, we gathered data on family law in seventy-one countries at four points in time: 1975, 1985, 1995, and 2005. We developed an index, described in Table 1, that identifies numerous ways in which the law promotes-or prejudices-women's autonomy and dignity. We counted these provisions and assigned each country a summary score. The higher the score, the less discriminatory the law. Countries with a score of thirteen have eliminated formal inequities in family law, at least legally.

TABLE 1. FAMiLy LaW INDEX

\begin{tabular}{|c|c|c|}
\hline Variable & Description & Score \\
\hline $\begin{array}{l}\text { Minimum } \\
\text { marriage age }\end{array}$ & $\begin{array}{l}\text { No minimum age of marriage or different } \\
\text { minimum marriage ages for women and } \\
\text { men }\end{array}$ & $\begin{array}{l}0=\text { yes } \\
1=\text { no }\end{array}$ \\
\hline Consent & $\begin{array}{l}\text { Marital consent is problematic; meaning, } \\
\text { one (or more) of the following conditions } \\
\text { holds: (1) the consent of people other than } \\
\text { the spouses themselves counts as consent to } \\
\text { marry (in other words, a woman's father can } \\
\text { consent to her marrying groom X even if the } \\
\text { woman does not want to); or (2) parental } \\
\text { consent is required even when people are } \\
\text { above the minimum marriage age }\end{array}$ & $\begin{array}{l}0=\text { yes } \\
1=\text { no }\end{array}$ \\
\hline Marriage ban & $\begin{array}{l}\text { The law forbids people (or some people-- } \\
\text { such as women) from marrying certain } \\
\text { categories or groups besides relatives (e.g., } \\
\text { Sunni from Shia Muslim, foreigners, people } \\
\text { of a different race). }\end{array}$ & $\begin{array}{l}0=\text { yes } \\
1=\text { no }\end{array}$ \\
\hline $\begin{array}{l}\text { Spousal rights } \\
\text { and duties }\end{array}$ & $\begin{array}{l}\text { Marital duties are patriarchal, for example, } \\
\text { by containing phrases such as "the husband } \\
\text { has the duty to support his wife and the } \\
\text { wife must obey him," or "the husband is the } \\
\text { head of the household." }\end{array}$ & $\begin{array}{l}0=\text { yes } \\
1=\text { no }\end{array}$ \\
\hline
\end{tabular}

23. See generally AILI MARI TRIPP ET AL., AFRICAN WOMEN'S MOVEMENTS: TRANSForming Political LANDSCAPES (2009); Baraza, supra note 16. 


\begin{tabular}{|c|c|c|}
\hline Guardianship & $\begin{array}{l}\text { The father holds and exercises parental power } \\
\text { or legal guardianship and the mother does not } \\
\text { have this right, or mothers and fathers have } \\
\text { equal rights to parental power in theory, but } \\
\text { the father is the one who exercises these } \\
\text { rights, for example, in the event of a } \\
\text { disagreement between the spouses. }\end{array}$ & $\begin{array}{l}0=\text { yes } \\
1=\text { no }\end{array}$ \\
\hline Name & $\begin{array}{l}\text { The law requires a common marital name. } \\
\text { This includes situations in which the } \\
\text { common name must be the man's name and } \\
\text { when there is no stipulation that the name } \\
\text { must be the man's name. (In practice, the } \\
\text { common name is almost always the man's } \\
\text { name.) }\end{array}$ & $\begin{array}{l}0=\text { yes } \\
1=\text { no }\end{array}$ \\
\hline $\begin{array}{l}\text { Marital } \\
\text { property } \\
\text { regime }\end{array}$ & $\begin{array}{l}\text { The marital property regime discriminates } \\
\text { against women. This means that one or } \\
\text { more of the following conditions holds: (1) } \\
\text { the husband has exclusive right to } \\
\text { administer and dispose of common property; } \\
\text { (2) the husband and wife may both } \\
\text { administer common property, but the } \\
\text { husband prevails in the event of a } \\
\text { disagreement or the wife otherwise has } \\
\text { fewer rights; (3) husband and wife can } \\
\text { administer their separate property but the } \\
\text { husband has control over the marital home } \\
\text { or other common assets (a common situation } \\
\text { in Islamic law); or (4) the husband is named } \\
\text { as head, boss, or chief of communal } \\
\text { property. }\end{array}$ & $\begin{array}{l}0=\text { yes } \\
1=\text { no }\end{array}$ \\
\hline Right to work & $\begin{array}{l}\text { Men have more rights to work than women } \\
\text { do (in family law). This means that one of } \\
\text { the following conditions holds: (1) wives } \\
\text { need their husbands' permission to work; or } \\
\text { (2) husbands can legally prevent their wives } \\
\text { from working. }\end{array}$ & $\begin{array}{l}0=\text { yes } \\
1=\text { no }\end{array}$ \\
\hline Divorce & $\begin{array}{l}\text { Men and women do not have equal rights to } \\
\text { divorce, or the grounds for divorce differ } \\
\text { between men and women, or the country } \\
\text { does not legally permit divorce. }\end{array}$ & $\begin{array}{l}0=\text { yes; } \\
1=\text { no }\end{array}$ \\
\hline $\begin{array}{l}\text { Custody after } \\
\text { divorce }\end{array}$ & $\begin{array}{l}\text { The law gives fathers guardianship or } \\
\text { custody of children following divorce, even if } \\
\text { the mother may have temporary custody. }\end{array}$ & $\begin{array}{l}0=\text { yes; } \\
1=\text { no }\end{array}$ \\
\hline
\end{tabular}




\begin{tabular}{|c|c|c|}
\hline $\begin{array}{l}\text { Property after } \\
\text { divorce }\end{array}$ & $\begin{array}{l}\text { The division of property after divorce favors } \\
\text { the man, for example, by (1) presuming that } \\
\text { he will keep common property such as the } \\
\text { marital home, even if the wife keeps her own } \\
\text { property; (2) denying the wife's economic } \\
\text { contribution to the marriage, even if she } \\
\text { worked only in the home; or (3) giving all } \\
\text { property to the man. } \\
\text { Note: if one of the following conditions } \\
\text { holds, the division of property is egalitarian: } \\
\text { (1) the property is divided evenly between } \\
\text { the spouses; or (2) husband and wife keep } \\
\text { the property they had prior to marriage, but } \\
\text { everything acquired or earned (including by } \\
\text { the husband's work) during marriage is } \\
\text { split evenly. }\end{array}$ & $\begin{array}{l}0=\text { yes } \\
1=\text { no }\end{array}$ \\
\hline Adultery & $\begin{array}{l}\text { Laws on adultery are more favorable to } \\
\text { men. This means that one of the following } \\
\text { conditions holds: (1) the law states-for } \\
\text { example, among the grounds for divorce- } \\
\text { that men commit adultery only by having a } \\
\text { long-term concubine whereas women } \\
\text { commit adultery by engaging in one sexual } \\
\text { act; or (2) the law exempts from criminal } \\
\text { punishment (or attenuates the punishment } \\
\text { of) men who murder their adulterous wives } \\
\text { (so called "honor killings"). }\end{array}$ & $\begin{array}{l}0=\text { yes } \\
1=\text { no }\end{array}$ \\
\hline \multirow[t]{2}{*}{ Inheritance } & $\begin{array}{l}\text { Men (sons, brothers, or widowers) inherit } \\
\text { more than women of equal status by law or } \\
\text { in the event of intestate succession. }\end{array}$ & $\begin{array}{l}0=\text { yes } \\
1=\text { no }\end{array}$ \\
\hline & TOTAL & $\begin{array}{l}13=\text { full } \\
\text { formal } \\
\text { sex } \\
\text { equality; } \\
0=\text { no } \\
\text { sex } \\
\text { equality }\end{array}$ \\
\hline
\end{tabular}

Our index gives equal weight to each indicator. However, it may be that not all areas of family law are equally important. In most cases, a woman's ability to request divorce or inherit property affects her life more than whether she must assume her husband's name upon 
marriage. In the future, we may weight the index so that more crucial areas receive more points.

In most countries, we coded national statutory law, whether civil, common, or religious. In federal countries, where civil laws are set by each state (or province), we coded precedent-setting federal court decisions establishing parameters for state laws.

Several countries in our sample have multiple legal systems, which presents a challenge for coding. In these countries, we coded national statutory law. Often enough, this consisted of civil or common law statutes inherited from the colonial period. Exceptions to this rule include India, where we coded Hindu Law, and Malaysia, where we coded Islamic Law.

We made this decision primarily for the ease and consistency of coding. Though customary law governs much of the population in subSaharan African countries, it varies and is often not codified. Civil or common law is not irrelevant to these groups, however. It is common for couples in Nigeria, for example, to marry under both customary and statutory law. ${ }^{24}$

\section{Country scores: a snapshot}

The maps in figures 1-4 show the approximate score of each country at four points in time.

The maps show that cross-national variation embraces almost our entire index. For example, almost half of the countries in the study (thirty-three of seventy-one) had a score of thirteen in 2005. Two countries, Egypt and Saudi Arabia, had the lowest scores of the sample: one.

Countries with a score of thirteen in 2005 include Australia, Austria, Belgium, Botswana, Brazil, Bulgaria, Canada, Colombia, Costa Rica, Croatia, the Czech Republic, Denmark, Finland, France, Germany, Greece, Hungary, Iceland, Italy, Kazakhstan, Lithuania, the Netherlands, Norway, Peru, Poland, Portugal, Romania, Russia, Slovak Republic, Slovenia, Spain, Sweden, and the United States.

Several countries began the period with lower scores and later reformed, including Morocco, Turkey, South Korea, Taiwan, Greece, Botswana, Brazil, Chile, Spain, and Switzerland.

The vast majority of countries with high scores in 2005-which reflects the absence of formal sex discrimination in family law-are European (including both Western and postcommunist countries) and Latin American.

24. Rahmatian, supra note 9 , at 282 . 
This uniformity has two different sources. The first is the sweeping wave of liberalization that transformed family law in the last third of the twentieth century in noncommunist countries. These reforms have their origin in social changes, including women's entrance into the labor force, a drop in fertility, a rise in marital breakdown and out-of-wedlock births; a change in public attitudes about gender roles; and the rise of the feminist movement. These factors are interrelated: the feminist movement transformed ideas about women's roles, which fueled other social changes. For example, as more women entered the labor market and gained access to education, they tended to use birth control, which led to fertility declines.

\section{FiguRE 1. 1975 FAMILY LAW INDEX}

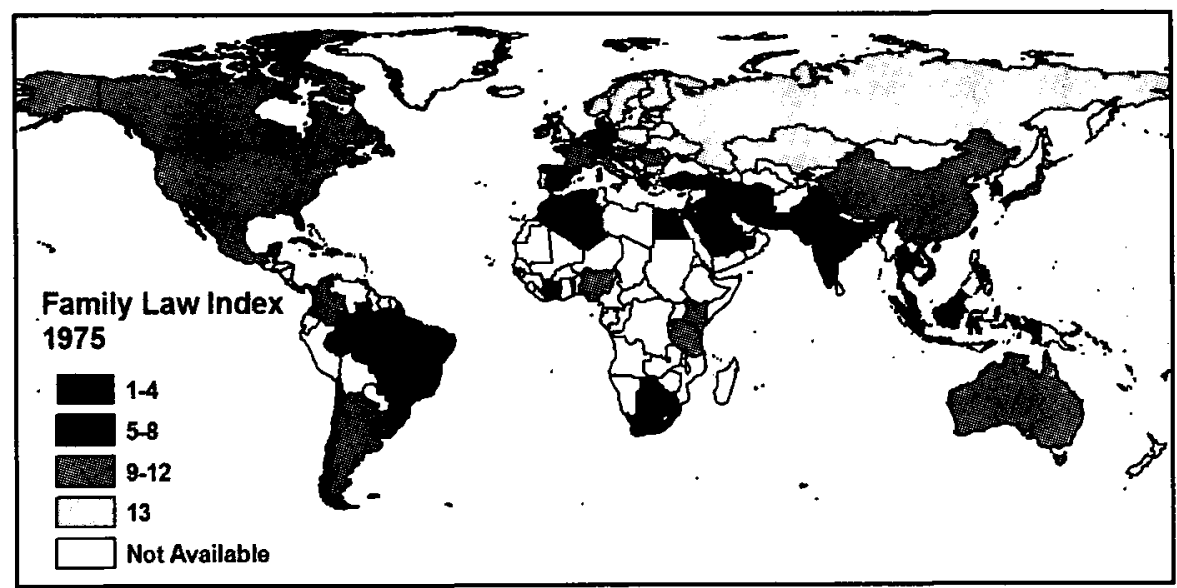

FIGURE 2. 1985 FAMILY LAW INDEX

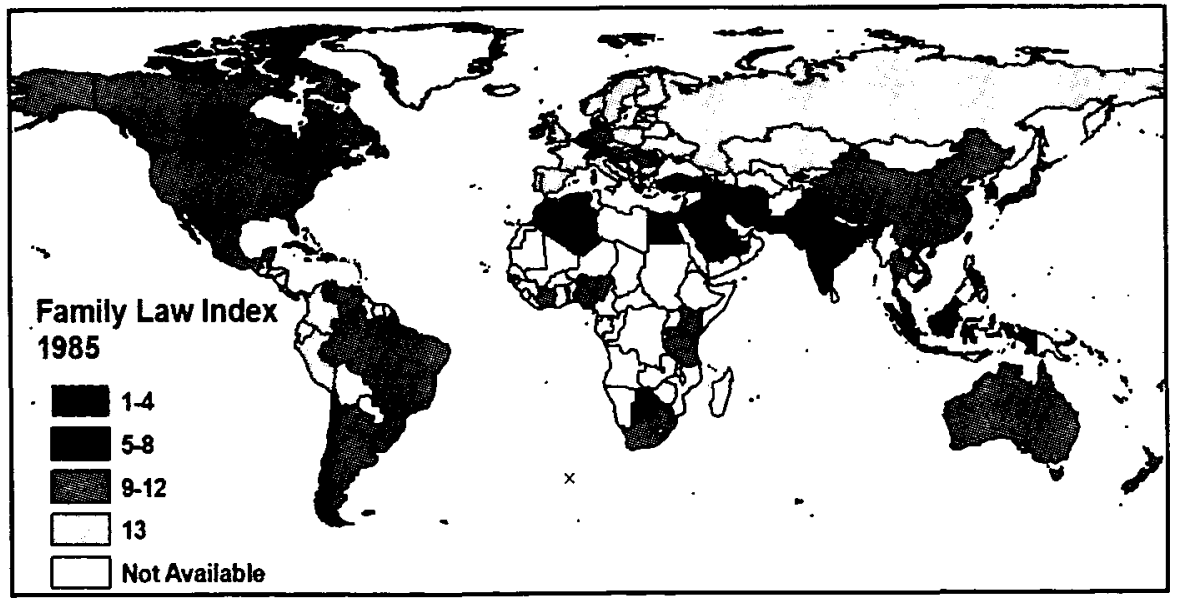


FiguRE 3. 1995 FAMILY LAW INDEX

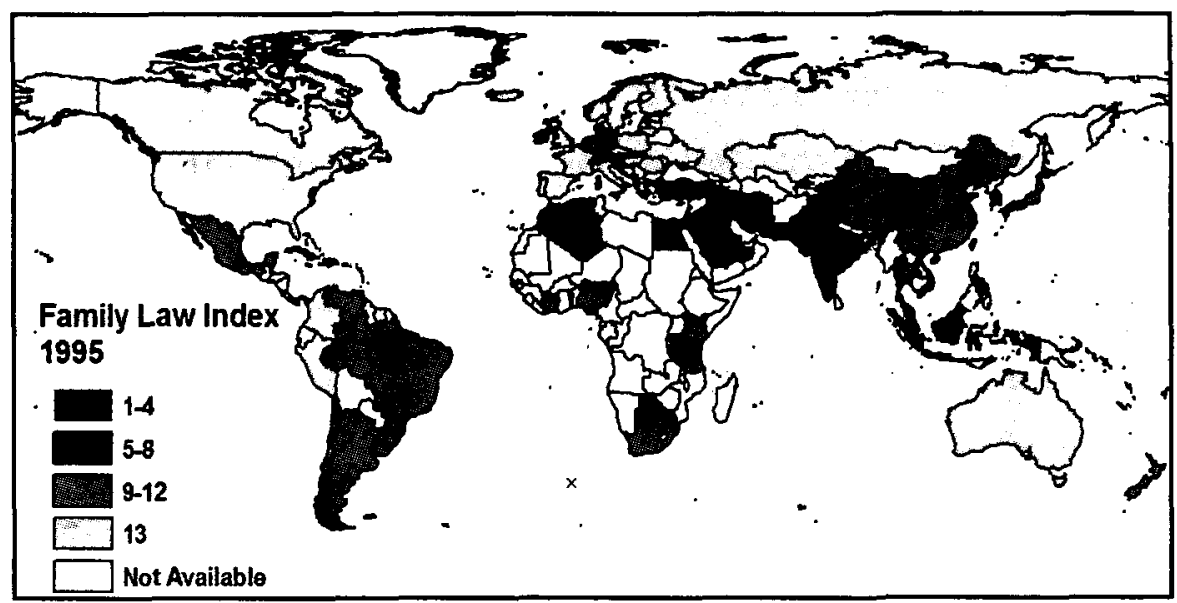

FIGURE 4. 2005 FAMILY LAW INDEX

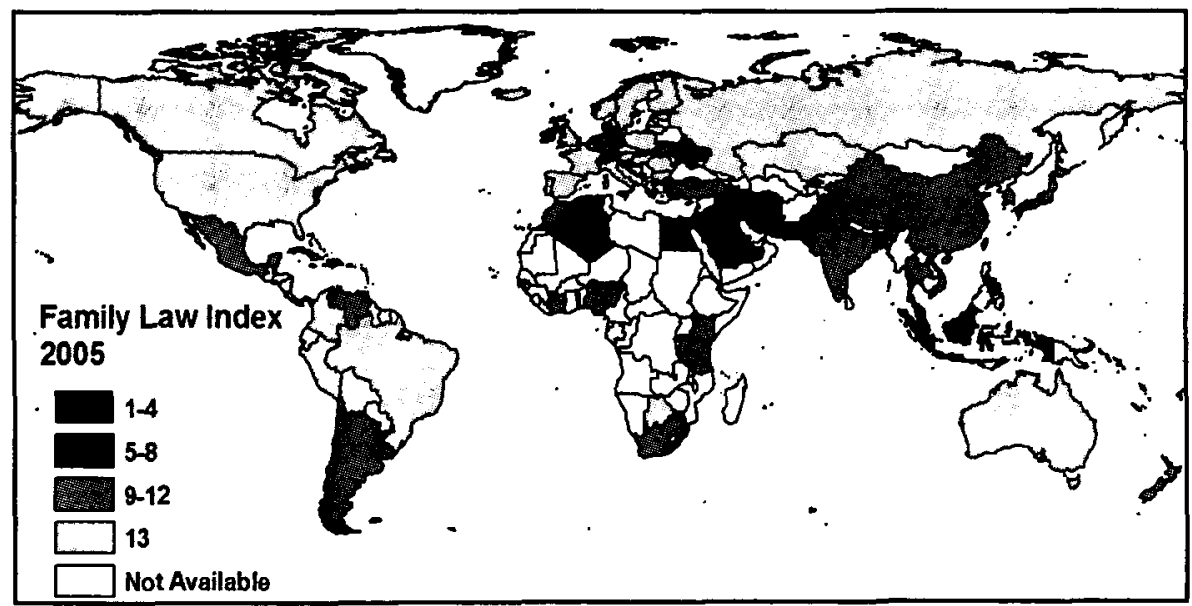

Against this backdrop, reformist coalitions mobilized to demand changes in restrictive, patriarchal family laws. These coalitions were not limited to feminist activists, but included lawyers, state officials, academics, and social workers. They joined together in issue networks by virtue of their shared interests in family law, not a broader agenda of sex equality or cultural change, which could encompass reproductive rights and other issues. Taking advantage of openings in state 
institutions offered by democratic transitions, ${ }^{25}$ the rise to power of a liberal or left-wing party, ${ }^{26}$ or the discrediting of religious institutions, ${ }^{27}$ they secured historic modifications of family laws governing women's and men's lives. ${ }^{28}$

The second trend characterizes the communist and postcommunist countries. This group introduced egalitarian family laws in line with official socialist ideology. Engels linked male domination in the family to private property, the linchpin of the capitalist system. ${ }^{29}$ The platforms of most communist parties called for sex equality in family law as a means of radical social transformation. Some of the founding legislation in communist countries consisted of family codes that eliminated patriarchal authority in marriage, made divorce easy to obtain, and banned religious or cultural practices such as child marriage. Examples include the Russian Family Code of 1926, the 1950 Chinese Marriage Law, the 1975 Cuban Family Code, and family laws promulgated in South Yemen in 1967 and Afghanistan in 1978. ${ }^{30}$ These laws were the result of the ideology of the ruling party, not broad-based civic advocacy. Their aim was less to promote women's rights than to crush the vestiges of religious authority, expand the size of the labor force, and promote massive social changes. ${ }^{31}$

Following the end of communism in the eastern bloc, most new states preserved their egalitarian family laws, although this was not the case in other areas of gender-related policy. Social programs-including childcare, parental leave, and health care-were often curtailed under the pressure of market-oriented economic reforms. Some states faced additional pressure to roll back permissive abortion laws. Ecclesiastical

25. Such as those in Argentina, Brazil, Chile, and Spain.

26. As occurred in Germany.

27. As occurred in Argentina, Brazil, Italy, and Spain.

28. See generally HTUN, supra note 8 (discussing the impact of political and social transitions on family law in Latin America).

29. Friedrich Engels, The Origin of the Family, Private Property, and the State, in THE MARX-ENGELS READER (Robert C. Tucker ed., 2d ed. 1978). For further discussion, see HTUN, supra note 8 , at 44.

30. Molyneux, supra note 3 , at 52-53, 55. On Russian family law, see Inga Markovits, The Death of Socialist Law?, ANN. REV. L. \& Soc. SCI., vol. 3, 2007, at 233, 249. See also Mala Htun, Gender Equality in Transition Policies: Comparative Perspectives on Cuba, in LoOKIng ForWard: Comparative Perspectives on Cuba's Transition 119 (Marifeli Pérez-Stable ed., 2007); Inga Markovits, Family Traits, 88 MICH. L. REv. 1734, 1743-47 (1990) (discussing MARY ANN GLENDON, The TRANSFORMation of FAMILY LaW: State, LAW AND FAMILY IN THE UNTED STATES AND WESTERN EUROPE (1989)).

31. Molyneux, supra note 3 , at 53. 
advocacy of stricter policies was most successful in Poland, which criminalized most abortions in $1993 .^{32}$

\section{ENDURING DiscRIMINATION}

Most of the world--but not all-had moved toward the elimination of sex discrimination in family law by 2005. Yet a sizeable group of countries kept many discriminatory laws on the books over these four decades. In these countries, women are required to obey their husbands; lack equal rights to guardianship over children, marital property, and inheritance; and are unable to obtain a divorce with the same ease as men; among other handicaps. Table 2 identifies those countries with the lowest scores of the study.

TABLE 2. COUNTRIES WITH MOST DisCRIMINATORY LAWS, 2005

\begin{tabular}{|l|}
\hline $\begin{array}{l}\text { Countries with Index Value } \\
\text { of } 5 \text { and Under in } 2005\end{array}$ \\
\hline Algeria \\
\hline Bangladesh \\
\hline Egypt \\
\hline Iran \\
\hline Jordan \\
\hline Malaysia \\
\hline Pakistan \\
\hline Saudi Arabia \\
\hline
\end{tabular}

All the low-scoring countries apply a strict version of Islamic religious law to family matters. Other countries applying religious law had low scores too, including Israel, which applies multiple religious laws in addition to civil law, ${ }^{33}$ and Nigeria, which applies Islamic, customary, and common law.

32. See generally Eleonora Zielińska, Between Ideology, Politics, and Common Sense: The Discourse of Reproductive Rights in Poland, in REPRoducing Gender: PouITICS, PUBlics, AND EverYDAY LifE AFTER SocialisM 23 (2000); Silke Steinhilber, Gender and Post-Socialist Central European Welfare States: Family Policy Reforms in Poland and the Czech Republic, 1990-2004 (January 2010) (unpublished Ph.D. dissertation, New School for Social Research) (on file with author).

33. As Ruth Halperin-Kaddari notes, "According to the 1953 Rabbinical Courts Jurisdiction (Marriage and Divorce) Law, rabbinical courts have exclusive jurisdiction in matters of marriage and divorce, which are completely governed by religious law. However, all other matters that are related to divorce disputes, from child custody and support through property claims, are under the jurisdiction of the civil court, unless they 
From an equal rights perspective, the version of Shariah law upheld in many national statutes is problematic. Women are required to obey their husbands. Polygamy is permitted; though in some cases, wives can insist that a marriage contract preclude it or that a husband seek her permission (or a court's) before marrying again. Unilateral divorce via a husband's verbal repudiation of his wife is legally recognized. The father is the legal guardian of children, even after divorce. Though women keep the property they had upon entering marriage, husbands administer common property during and after marriage. ${ }^{34}$

What's more, very few of the low-scoring countries experienced any change over time. Most religiously inspired laws stayed the same over the four decades when women's rights around the world underwent radical transformation.

The Muslim world experienced a powerful push against liberalization: the Iranian Revolution of 1979. Ayatollah Khomenei reversed the liberalization of family law that had occurred under the secular government of the Shah. Revolutionary clerics called for religious orthodoxy around the Muslim world and the reinstatement of the Shariah. They upheld an example of a religious state led by clerics that was able to resist the decadence of the West, producing diffusion effects that empowered fundamentalists and undermined reformers. ${ }^{35}$

There have been numerous movements to reform family law in the Muslim world and several have succeeded in softening the edges of discrimination. Our index does not always capture these moments of success. For example, in Egypt, a reform approved in 2000 granted women the right to request no-fault divorce in court instead of having to prove cause during months of legal proceedings. Even this small victory required a massive coalition, involving President Mubarak, women's rights activists, lawyers, and Muslim scholars who offered Islamic

are properly 'attached' to a divorce suit filed in the rabbinical court." WOMEN IN ISRAEL: A STATE OF THEIR OWN 233 (2004).

34. Several countries have introduced provisions permitting a woman and her children to continue living in the marital home. For more information about the legal status of women in various countries with Shariah, see generally ESPOSITO WITH DELONG-BAS, supra note 7; ZIBA MIR-HOSSEINI, MARRIAGE ON TRIAL: A STUDY OF ISLAMIC FAMILY LAW (rev. ed. 2000); WOMEN LIVING UNDER MUSLIM LAWS, A HANDBOOK ON FAMILY LAW IN PAKISTAN (1994); Sisters in Islam, Malaysia, Islamic Family Law and Justice for Muslim Women, ASIA SOCIETY (May 31, 2001), http://asiasociety.org/policy-politics/socialissues/women-and-gender/islamic-family-law-and-justice-muslim-women?order=ASC.

35. The Iranian story demonstrates that what may seem like continuity and homogeneity across the Muslim world is, in reality, the outcome of a political process of propping up weak states in the context of contests between religious and secular (often even military) authority. 
justifications for the reforms. ${ }^{36}$ Though the reform was a step closer to equal rights, women are still disadvantaged relative to men, who may pronounce divorce unilaterally. What's more, they are required to return the dowry the husband paid under the terms of the marriage contract and forfeit the right to maintenance granted them under Islamic law.

In Malaysia, family law for most Muslims is governed by the Islamic Family Law (Federal Territories) Act of 1984. Under this law, which conforms fairly closely to classical Islamic law, a father serves as legal guardians of his children. In 1999, however, Malaysian civil law governing non-Muslims was modified to grant equal guardianship rights to mothers and fathers. Islamic feminists have lobbied for a similar reform of Muslim family law. In response, the government issued an administrative act granting mothers (as well as fathers) the right to sign a child's application for school, an identity card, and a passport. This decree softened the edges of the paternal authority upheld in the Shariah. ${ }^{37}$

Other efforts at reform have failed. Jordan has attempted to modify its personal status law to grant women greater rights several times since the early $1990 \mathrm{~s}^{38}$ In the early 2000s, several liberalizing amendments were enacted by temporary royal decree when Parliament was in suspension. ${ }^{39}$ These included an increase in the minimum marriage age to eighteen for both sexes; a requirement that wives be informed if their husbands contracted additional marriages; and extension to women of the right to no-fault divorce (similar to the Egyptian reform of 2000).40 After 2003, a reinstated Parliament was required to approve the changes in order for them to endure. ${ }^{41}$ In spite of vigorous lobbying by the royal family and passage in the upper house, the lower house of Parliament continued to vote against these (relatively small) alterations to classical Islamic family law. ${ }^{42}$

Jordan's experiences illustrate a potentially broader trend: parliamentary advocacy of strict versions of Shariah by Islamist parties. As they compete with extremists on the one side and more liberal groups on the other for recognition as the legitimate spokespersons of Muslims, Islamist representation in Parliament has grown in several

36. See Howard Schneider, Women in Egypt Gain Broader Divorce Rights; Wide Coalition Pushed for Legal Equality, WASH. POST, Apr. 14, 2000, at A16. For a criticism of the reforms as not going nearly far enough, see HUMAN RIGHTS WATCH, supra note 9.

37. See Sisters in Islam, supra note 34.

38. Janine A. Clark \& Amy E. Young, Islamism and Family Law Reform in Morocco and Jordan, 13 MEDITERRANEAN POL. 333, 337 (2008).

39. Id.

40. Id. at 337-38.

41. Id. at 337 .

42. Id. at 338 . 
countries. Family law figures prominently in the struggle for power between Islamists and their more secular counterparts. ${ }^{43}$

\section{The Chance to Change}

This article may have given the impression that patterns of family law are largely culturally specific and path dependent. The differences between the West-including Latin America and the postsocialist space-and the Muslim world are significant. This scenario conforms to some recent scholarship finding a gender gap between the two zones (though explanations for this gap vary, with some pointing to culture and others pointing to oil rents ${ }^{44}$ ) and linkages between the subordination of women and the lack of democracy in the Islamic world. 45

Notwithstanding the overall differences in scores, we should not think that any country's family laws are stuck in a particular cultural or historical path. Many countries-including Muslim ones such as Morocco and Turkey-have reformed highly discriminatory laws in favor of sex equality and some have done so virtually overnight.

On the next page, Table 3 lists those countries with the biggest changes between 1975 and 2005 (countries whose scores changed by four points or more are included).

43. See Valentine M. Moghadam, Globalization and Social Movements: ISLAMISM, FEMINISM, AND THE GLOBAL JUSTICE MOVEMENT 44-45 (2009).

44. Ronald F. Inglehart \& PipPa NorRis, Rising Tide: Gender Equatity and Cultural Change ARound THe WorLd 49-71 (2004). On the debate, see Michael Ross, Oil, Islam, and Women, 102 AM. PoL. SCI. REV. 107 (2008). For several articles on the debate, here titled "Debate: Does Oil Wealth Hurt Women?," see the contributions in 5 POL. \& GENDER, issue 4, 2009.

45. See generally Fish, supra note 4. 
TABLE 3. BigGest CHANGES, 1975-2005

\begin{tabular}{|l|r|}
\hline Country & Change in score \\
\hline Morocco & +8 \\
\hline Turkey & +8 \\
\hline South Korea & +7 \\
\hline Greece & +6 \\
\hline Taiwan & +6 \\
\hline Botswana & +5 \\
\hline Brazil & +5 \\
\hline Chile & +5 \\
\hline Spain & +5 \\
\hline Switzerland & +5 \\
\hline Iran & -4 \\
\hline Algeria & +4 \\
\hline Canada & +4 \\
\hline Germany & +4 \\
\hline South Africa & +4 \\
\hline Thailand & +4 \\
\hline
\end{tabular}

Morocco's reforms, which amounted to an overhaul of its Family Code (Moudawana), demonstrate that dramatic reform is possible. Dating from 1958, the original code had conformed almost completely to classical Islamic family law. ${ }^{46}$ In the intervening years, the code had undergone some minor reforms, including elimination of the requirement that married women seek their husband's permission to work and improving women's custodial and guardianship rights. ${ }^{47}$

Beginning in the $1990 \mathrm{~s}$, feminist activists began to mobilize around a proposal for more profound reforms and gathered one million signatures on a petition to then-monarch King Hassan II. ${ }^{48}$ In 1999 , the idea gained momentum, leading to the socialist-led government's announcement of a national plan to integrate women into development, including a series of radical changes to family law and other policies. ${ }^{49}$ Though an estimated 50,000-100,000 people demonstrated in favor of the plan at the capital, the Islamist countermarch was ten times bigger. ${ }^{50}$ The government shelved the development plan and the new monarch, King Mohammed VI, convened a high-level royal advisory commission (including religious scholars, lawyers, and activists) to

46. See CHARRAD, supra note 8, at 162-68; see generally GUIDE TO EQUALITY IN THE FaMILY IN THE Maghreb (Chari Voss trans., Ahmad Kazemi Moussavi ed., Women's Learning P'ship for Rts., Dev. \& Peace 2005) (2003).

47. See CHARRAD, supra note 8 , at $162-68$

48. Clark \& Young, supra note 38 , at 336 .

49. Id.

50. Id. 
deliberate and submit a proposal for reform. ${ }^{51}$ After a few years of closed-door meetings, the commission presented its report to the king. In January 2004, four months after the king's historic speech to Parliament, the legislature adopted a new Family Code bill unanimously, with the participation of the Islamist Party of Justice and Development. ${ }^{\text {2 }}$

The monarch's role was obviously critical to the success of the reform. What were his motivations? The 2004 reform was framed as the final culmination of a process of state building that had begun with the 1958 Personal Status Law. That code had helped to create the rule of law in the kingdom through unification, codification, and alliances with tribes adhering to Islamic norms. ${ }^{53}$ During his reign from 1961 to 1999 , King Hassan II established the principle of equal constitutional rights, permitting women to gain prominence in national life. His successor, King Mohammed VI, sought to complete the process by promoting democratization. With arguments straight out of feminist theory, he envisioned the family as the hub of profound social change. As the preamble to the new law stated:

His Majesty King Mohamed VI, may God glorify him-in order to illustrate his commitment to the policies of local democracy and participation ... has insisted, may God protect him, on making the Moroccan family-based upon shared responsibility, affection, equality, equity, amicable social relations and proper upbringing of children-a substantial major component of the democratization process, given that the family constitutes the essential nucleus of society. ${ }^{54}$

The justification for the new law came from within the Shariah. It stated that, in presiding over the royal commission who proposed reforms, the king had "insisted upon their fidelity to the provisions of Sharia (religious law) and Islamic principles of tolerance, and encouraged the use of ijtihad (juridical reasoning) to deduce laws and precepts." ${ }_{55}$ Religious justification for the new changes helped disarm opponents. Likewise, this reform demonstrates that the Shariah is subject to multiple interpretations, some of which endorse sex equality.

51. Id.

52. Id. at 336-37.

53. See ChARRAD, supra note 8 , at 161-67.

54. Decree to Implement Law No. 70.03 as the Family Code, Law No. 70.03, Dahir No. 1-04-22, Feb. 3, 2004, pmbl.

55. Id. 
The king's intervention was carefully timed and took advantage of a window of opportunity. A few months before his speech, terrorist attacks in Casablanca killed and wounded dozens of people. ${ }^{56}$ The attack put Islamic fundamentalists on the defensive. ${ }^{57}$ As a result, they fared poorly in national elections and dared not oppose the reforms. ${ }^{58}$

Similar conjunctural moments-dramatic events, political transitions, realigning elections-assisted the cause of reformers in other countries. In Canada, the adoption of the Canadian Charter of Rights and Freedoms (the "Charter") helped feminists prevail over opposition from antifeminist movements in their battles over family law. 59 The demise of the Franco regime and the Spanish transition to democracy paved the way for the enactment of equal rights in the 1978 Constitution and the further liberalization of family law with the legalization of divorce in 1981. Roman Catholic bishops who ardently opposed divorce had lost political capital due to their support for the ancien regime. The new government was therefore able to promulgate reforms opposed by the Church but supported by society at large.

In Germany, the Social Democrats under Willy Brandt's chancellorship promoted social reforms and greatly expanded the size of the welfare state in the late 1960s and early 1970s. Around the same time, the government created a commission to discuss reforms to the law on marriage, divorce, and support provisions, which culminated, after extensive legislative and societal discussion, in promulgation of a new law on marriage and divorce in 1976. The law replaced a patriarchal image of marital power with the declaration that "the spouses conduct the running of the household by mutual agreement." 60 It eliminated causes for divorce by establishing that divorce would be available only for a single, no-fault ground and by changing rules on alimony so that it would be available only to help an economically weak spouse for a temporary period. 61

\section{CONCLUSION}

A majority of the world's countries have reformed family law to eliminate, at least partially, provisions that discriminate against

56. Clark \& Young, supra note 38 , at 339.

57. See id. at 340 .

58. See id.

59. See Sylvia Bashevkin, Women on the Defensive: Living Through Conservative Times 91 (1998).

60. GLENDON, supra note 1, at 93 (quoting Erstes Gesetz zur Reform des Ehe- und Familienrechts [EheRG], June 14, 1976, BGBL. I at 1421, § 1356(1)).

61. GLENDON, supra note 1 , at 219. 
women. As this article has shown, a significant number continue to uphold sexist laws. Why? What is it about family law that resists change? How is family law different from issues that entered political agendas more recently, such as violence against women, gender quotas, and workplace equality, where progress has been made?

Historically, institutionalized relations between the state on the one hand, and organized religion, clans, and cultural groups on the other hand, have endowed the latter with authority over family law. Reforms touching upon the allegedly central tenets of religious doctrine, cultural tradition, and the sacred discourse of social groups challenge state deference to religious authority. Specifically who and what is being threatened by these reforms varies from place to place. Roman Catholic bishops long claimed that the legalization and liberalization of divorce would undermine the institution of marriage and weaken the family, leading to social anomie and breakdown. Islamist parties and their allies today argue that granting women equal rights to divorce and restricting polygamy undermine national identity, morality, and values, in addition to weakening the family and society. Tribal authorities in sub-Saharan Africa reject women's land and inheritance rights on the ground that they violate local customs. ${ }^{62}$

In fact, family law has been reformed in many places, such as Morocco, Brazil, and Spain, without the consequences feared by opponents. This raises questions about whether the survival of the family, religion, or national identity is really at stake. At issue, rather, is the question of who decides how family relations should be structured. Family law reform provokes fierce opposition because it threatens to transfer control from religious authorities to secular bodies and to shift weight in favor of alternative interpretations of religious traditions. The goal of opponents is not to defend religion, culture, and tradition but to uphold the status quo. Family law reform, like other political conflicts, revolves around the struggle for power.

62. See generally TRIPP ET AL., supra note 23; Baraza, supra note 16. 


$$
\text { - }
$$

